\title{
La Canción del Río
}

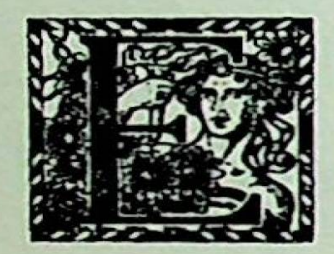

L rio se viene cantando, cantando, como un hechicero de la soledad. Arboles y riscos se quedan vibrando cuando pasa el río, camino del mar.

El río se viene cantando, cantando,

y es una alegría sentirlo pasar.

Tendido en la hierba, si el agua me toca las manos morenas quemándose al sol, y el viento sureño me llena la boca, yo siento que el río, la tierra y la roca laten con la sangre de mi corazón.

Tendido en la hierba, si el agua me toca, bendigo la fuga del río cantor.

La canción del río se pierde en el llano. Los hombres del valle no tienen canción. Un murmullo apenas refresca el verano de este silencioso pueblo labrador.

La canción del río se pierde en el llano como si del agua se fuera el amor. 
El rio venía cantando, cantando, desde la montaña que nieve le dió.

Las piedras sonoras quedaron sonando, y en el valle el río su canción perdió.

El río venía cantando, cantando; desde muy arriba cantando bajó. Por el valle estrecho se aleja llorando, y ninguno sabe que el río cantó. 